\title{
The Evaluation of Municipal Landfill Sites in North of Iran through Comparing BC Guideline and Iran Legislation
}

\author{
Mohadeseh Yazdani ${ }^{1}$, Masoud Monavari ${ }^{1}$, Ghasem Ali Omrani ${ }^{2}$, Mahmoud Shariat ${ }^{2}$, \\ Mohsen Hosseini ${ }^{3}$ \\ ${ }^{1}$ Department of Environmental Science, Graduate School of Environment and Energy, Science and Research Campus, Islamic Azad \\ University, Tehran, Iran; ${ }^{2}$ Tehran University of Medical Sciences, School of Public Health, Tehran, Iran; ${ }^{3}$ Department of Forestry, \\ Faculty of Natural Resources, Tarbiat Modares University, Noor, Iran. \\ Email: Mohades_yazdani@yahoo.com,monavarism@yahoo.com,Omraniyh@hums.ac.ir, shariatm@yahoo.com, \\ hosseini@modares.ac.ir
}

Received May $1^{\text {st }}, 2013$; revised June $8^{\text {th }}, 2013$; accepted June $28^{\text {th }}, 2013$

Copyright (C) 2013 Mohadeseh Yazdani et al. This is an open access article distributed under the Creative Commons Attribution License, which permits unrestricted use, distribution, and reproduction in any medium, provided the original work is properly cited.

\begin{abstract}
Selection of landfill site is a complex process which demands many diverse criteria. The significance of the present study lies in the fact that it tends to evaluate the suitability of the existing municipal landfill sites in the west area of Mazandaran province, located in north of Iran, and the south coast of Caspian Sea. In order to carry out this evaluation, 3 guidelines are used. After reviewing all the specified criteria in each of the guidelines, the authenticity of each deposit site of the study area and the entire area also was examined; and eventually the appropriate areas were identified. As a result, 62.38 percent of the study area according to the guideline of British Columbia, 25 percent according to the Iran department of environment, and the 48.5 percent according to the management and planning organization of Iran are suitable for landfill siting.
\end{abstract}

Keywords: Landfill Siting; Evaluation; Siting Criteria; BC; DOE; MPO

\section{Introduction}

In developing countries, in spite of the increasing stress toward the waste reduction at the source, the disposal of landfilling has remained the most commonly employed method. Landfill sitting is a complex process, for which various techniques have been developed $[1,2]$. These techniques, through using multiple factors, attempt to reduce negative effects on environment. In landfill siting, in order to reduce negative impacts on the environment, a wide range of territorial and legal factors should take into account [3].

The development of a municipal solid waste landfill requires the acquisition of large tracts of land and their suitable siting in a pre-existing urban matrix, comprised of diverse competing land uses [4]. The site selection procedure, however, should make maximum use of the available information and ensure that the outcome of the process is acceptable by most stakeholders. Therefore, landfill siting generally requires the processing of a variety of spatial data [5]. GIS plays a significant role in siting landfills. The potential advantage of a GIS-based approach to siting arises from the fact that it not only reduces the time and cost of site selection but also pro- vides a digital data bank for long-term monitoring of the site [6]. The truth that the municipal solid waste management in Iran is in critical conditions, is not a secret [7]. Unfortunately in most cities of Iran, even the simplest method of waste disposal landfill does not apply [8]. Despite the increasing advances in modern methods of locating waste landfills in the world, unfortunately, 49 percent of the total solid waste disposal methods in Iran is piled up and unsafe for disposal [9]. There are so many problems associated with the landfill sites across the country, and there is no exception in this province as well. The problems include open-air waste burning, open-pit dumping and uncontrolled waste disposal in landfills, which can result in negative impacts on public health and on environment [10-12]. The west area of Mazandaran, due to its topographic conditions (forest and sea close together), its high groundwater levels, its high tourist population (especially in spring \&summer) has more critical status than the other parts of the province.

\section{Area of Study}

The studied area measures $8761.5 \mathrm{~km}^{2}$, and is located in the west of the province of Mazandaran on the Northern 
edge of Iran, in the south coast of Caspian Sea (Figure 1). About 20.87 percent of the population of the province of Mazandaran is concentrated on a surface area of 8761.5 $\mathrm{km}^{2}$, i.e. about 36.88 percent of the entire area [13]. In this area there are 10 land fills which are used to dispose and eliminate waste from 12 municipal districts, whose 610120 inhabitants generate about $216000 \mathrm{t}$ of waste per year. Located between Alborz mountain range and Caspian Sea, the studied area's elevation difference is between -27 to almost around 4800 meters. In terms of geomorphological condition, the area contains three units of coastal plains, foothills and mountains. The weather in plains and low hills is temperate and humid, and that is cold in the heights of mountains [14].

\section{Materials and Methods}

The presence of a landfill in this area has an influential effect on the environment. Its impact is largely dependent on the affected elements of the site as well as on the spatial distribution of the effects. The first step in the evaluation of the environmental impact of the landfill is the identification of any element, which may be sensitive to this impact. In many literatures several techniques for landfill sitting can be found. These techniques are used to evaluate the siting suitability; but in this study the compliance status landfill sites in West cities of Mazandaran province were compared with two national and one international standard. In the present study 10 municipal waste landfills in 12 municipal districts were evaluated through three following methods: the guidelines of British Columbia (BC), Iran department of environment (DOE), and Iran management and planning organization (MPO).

Each system, indicated in Table 1, evaluates waste sites for one or more hazard migration route (s), namely ground water, surface water, soil. Land fill sites include: Ramsar, Tonkabon, Abasabad, Kelardasht, Salmanshahr, Kelar abad, Chalus, Marzanabad, Noshahr and Noor [shown in (Figure 2)].

Application of the methodology is based on the collection of data relating to the physical environment, state and characteristics of deposit points.

Data collection involved visiting the different deposit points as well as studying the existing information, regarding the points and characteristics of their environment [15] .In this study, 15 input map layers including, surface water (rivers and lakes), flood plain, ground water (springs and wells),distance to airport, land use (agricultural land, forest land, and special land), Sources of drinking water, Distance to residential areas, road distance to waste production centers, geology (fault, bedrock, Seismicity) were considered.

\subsection{Preparation and Investigation of Thematic Maps with GIS Software}

Over the last few years, GIS has emerged as an influential tool for land use suitability analysis. GIS can recognize, correlate and analyze the spatial relationship be-

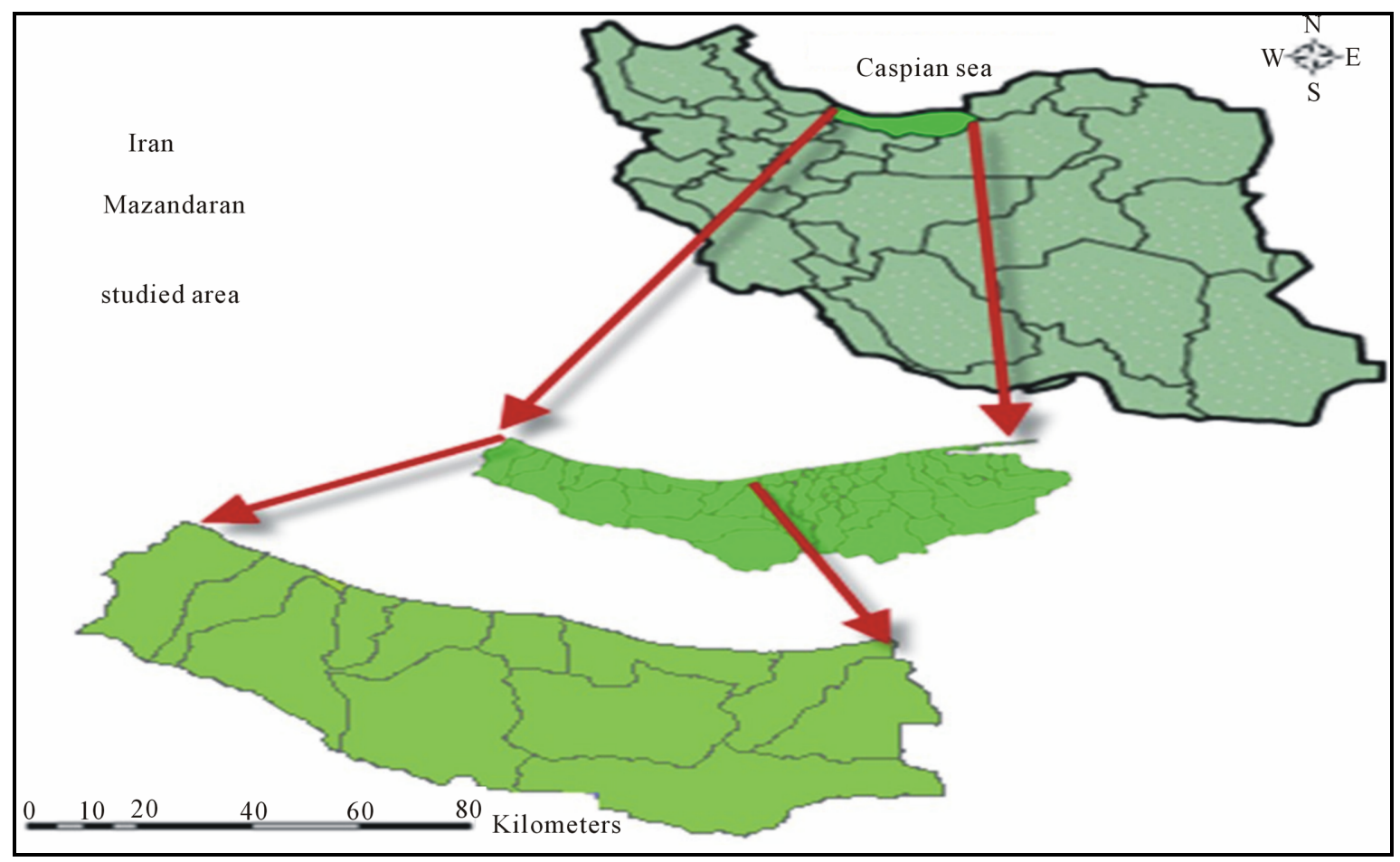

Figure 1. Area of study. 


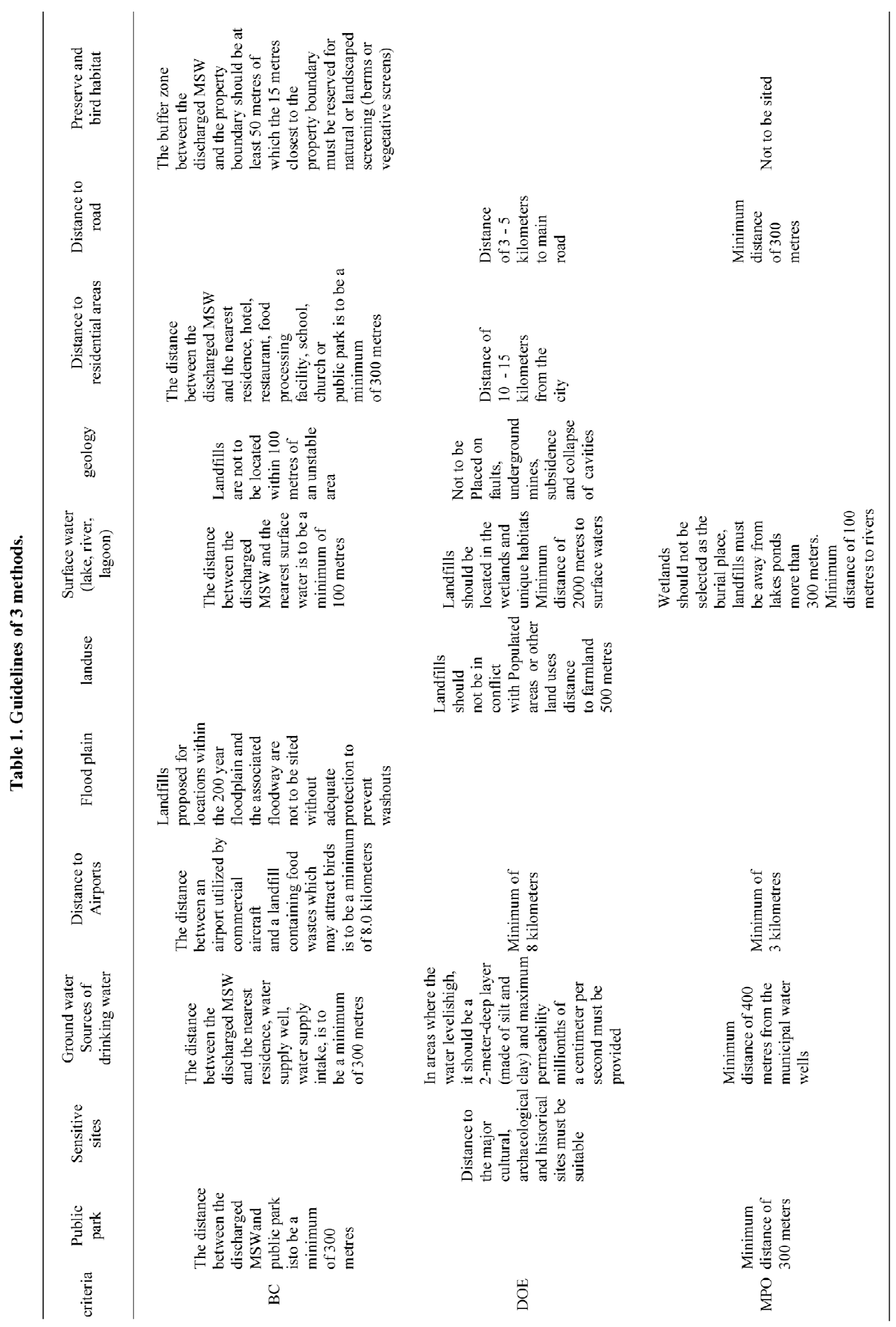




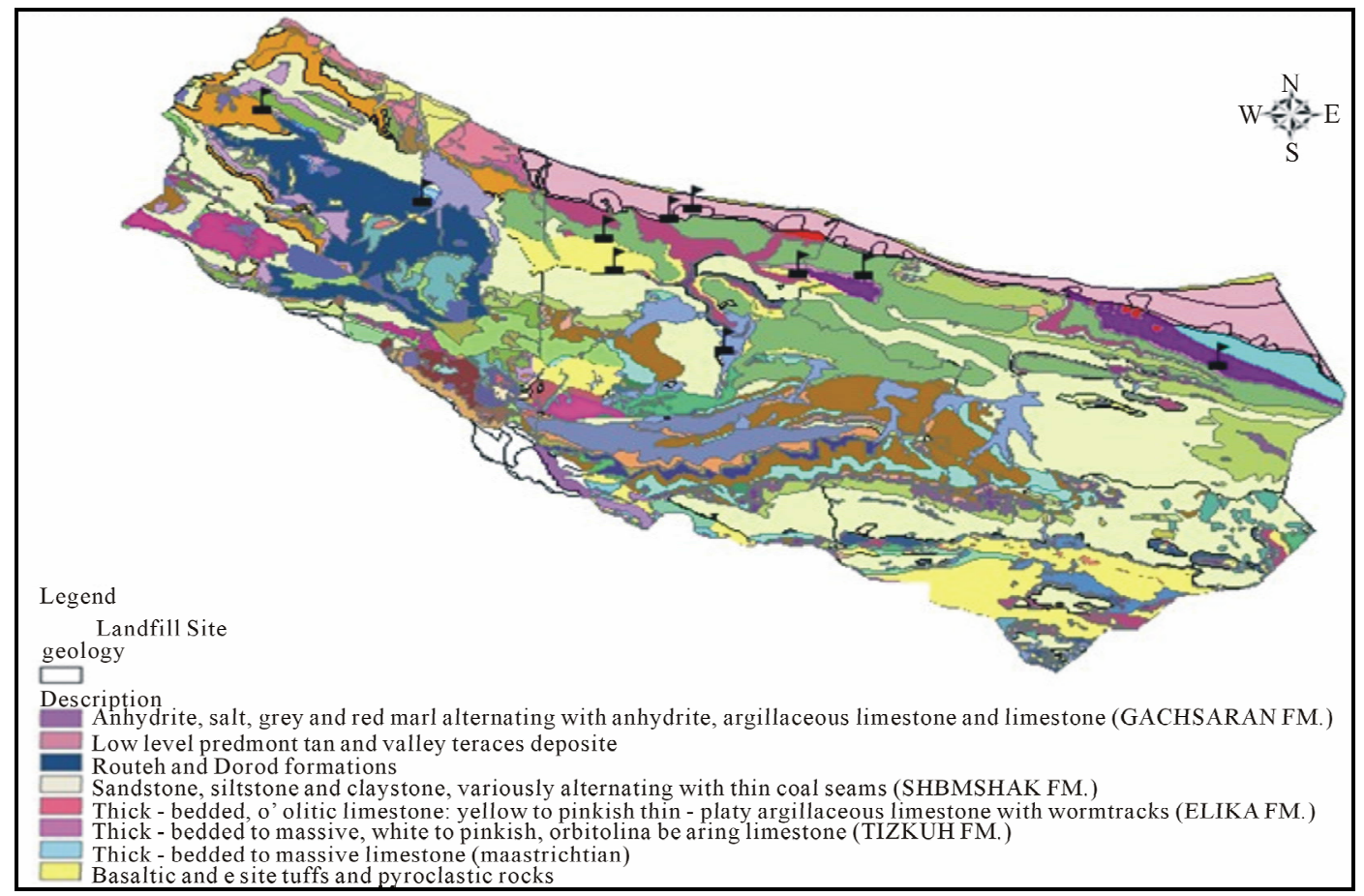

Figure 2. Location of landfill sites.

tween mapped phenomena, thereby enabling policymakers to link disparate sources of information, toperform sophisticated analysis, to visualize trends and project outcomes, and also to strategize long-term planning goals [16].

The landfill sites map layer is prepared by locating the GPS coordinates of landfill sites and entering them as latitude and longitude in the GIS software database, and then converting them into the point data. Buffer maps indicating regions encompassing appropriate areas from lakes, rivers, water supply sources, protected area, highways and fault line were also generated to act as 'areas of constraints', i.e., where a landfill can not be sited.

\subsubsection{Evaluation Criteria}

- Surface water (Hydrology) map:

Surface water map indicates the existing lakes, wetland and rivers in the studied area. Because of the specific conditions of climate, there are multiple rivers around twenty main rivers and a lake, Valasht, in this area.

- Road network map:

The road network map delineates the national highways and other major roads of the studied area. There are seven (7) major roads and 21 (twenty one) highways in the region.

- Land use map:

The land use map displays the land utilized by human or the natural cover in the region. Relatively dense forest zone (Hyrcanian forest) covers most of the land surface in the studied area.

- Ground water source(Hydrogeology) map:

This map displays the wells and springs in this area; there are 20592 wells and 166 springs in the studied area.

- Residential areas map:

This map displays the existing cities and villages; there are 18 cities and around 1198 villages in the studied area.

- Geology map:

This map shows that Shemshak formation is the most geological unit in the studied area, and its typicality is alternating coal-bearing sandstone and shale.

- Sensitive sites map:

This map layer displays the cultural and historical and archaeological area, these sites are exempted from landfill siting and they have a safe distance.

- protected area sites map:

The map displays the protected areas, under the management of the Department of the Environment (DOE), which are around $39 \%$ of the studied area.

- Flood plain map:

This map shows that $210.5 \mathrm{~km}$ equivalent to about 2.4 percent of studied area is at risk of flooding.

- Infiltration Map :

An infiltration map displays the various soil types existing in the studied are. The infiltration rate is an important determinant in assessing the potential risk of contamination groundwater and thus is a major criterion for the development of landfill in the study area. We use this map to estimation of ground water level and soil type in this area. 
- Seismicity:

This map displays seismic zoning. It shows 3 zones with the very high seismicity risk in the south of the studied area, the high risk at center of region, and the medium risk in northern part of it.

- Faults map:

This map displays the existing faults in this area. The areas without faults or the ones which have a safe distance from the faults are suitable for landfill sitting. Faults increase permeability of rocks, therefore water ground may be polluted with leachate of landfill (or) in this study, this sub-criterion is divided in two components, major faults and minor faults.

- Airport map:

There are two airports in this area namely, Ramsar and noshahr.

\subsubsection{Buffer Maps}

Different criteria are used to obtain GIS dat sets of the buffer zone for, rivers, roads, water supply sources, fault lines, protected area, Maps exhibit the permissible distance beyond which the landfill can be sited for various criteria using the buffer option in ArcGIS. They were generated on the basis of existing standards which are indicated in Table 1 .the areas within the buffer are unsuitable for landfill development for solid waste disposal. They were generated on the basis of British Columbia guideline, existing standard sand regulatory requirements of Iran department of environment and the Iran management and planning organization. For example, in order to generate the buffer for rivers in $\mathrm{BC}$ guideline and the Iran management and planning organization, the rivers in the study area were considered and a buffer distance of 100 metres was applied around each of them. In DOE regulatory requirements, a buffer distance of $2000 \mathrm{~m}$ was applied. Similarly, buffer zones for roads, protected areas, water supply sources and fault lines and other criteria were created at a distance which is mentioned in Table 1. A GISbased overlay analysis was performed to identify the optimum site for the land fill, the one which fulfills all the desired attributes. Overlay of generated buffer maps were done in order to identify sites where the constraints parameter will be employed (sites not permissible for landfill).

After reviewing all specified criteria in each of the guidelines, the authenticity of each deposit site in the study area was identified; while the entire study area was also examined with the same criteria, and the appropriate areas were identified.

\section{Result}

After the preparation of thematic maps characterizing the influencing factors and the preparation of the GIS database for evaluation of landfill sites, the thematic maps were generated, overlaid upon one another and the above proposed algorithm was run on them and GIS based analysis was performed. The GIS-based constraint mapping technique was applied to the entire study area and after reviewing all sites with GIS maps and field views, it was found out that all sites are suitable with $\mathrm{BC}$ criteria except Salmanshahr and Kelarabad sites because of their proximity to road and Surface water resources, and Noshahr site because of its natural landscapes; and all sites are unsuitable with MPO criteria because they are located in the forest ecosystem except Marzanabad site. But Considering DOE criteria, all sites are unsuitable because they are located in areas with high seismicity risk, inadequacy of the area for landfill sitting or access to the landfill site .The entire study area was also checked and thus, the suitable and unsuitable areas were indicated. Regarding the final map layer, the appropriate areas were identified for landfilling which are mentioned in Table 2. The suitable area after the elimination of unsuitable regions was specified (see Figures 3-5).

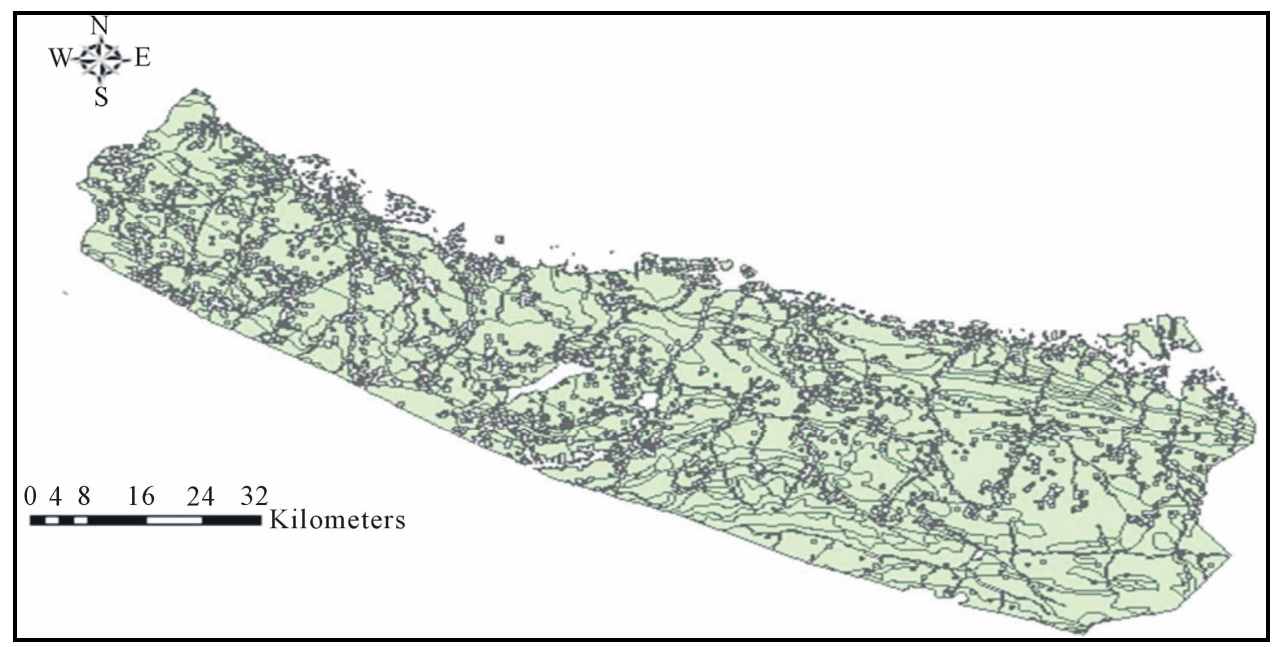

Figure 3. The suitable region of study area with BC criteria. 


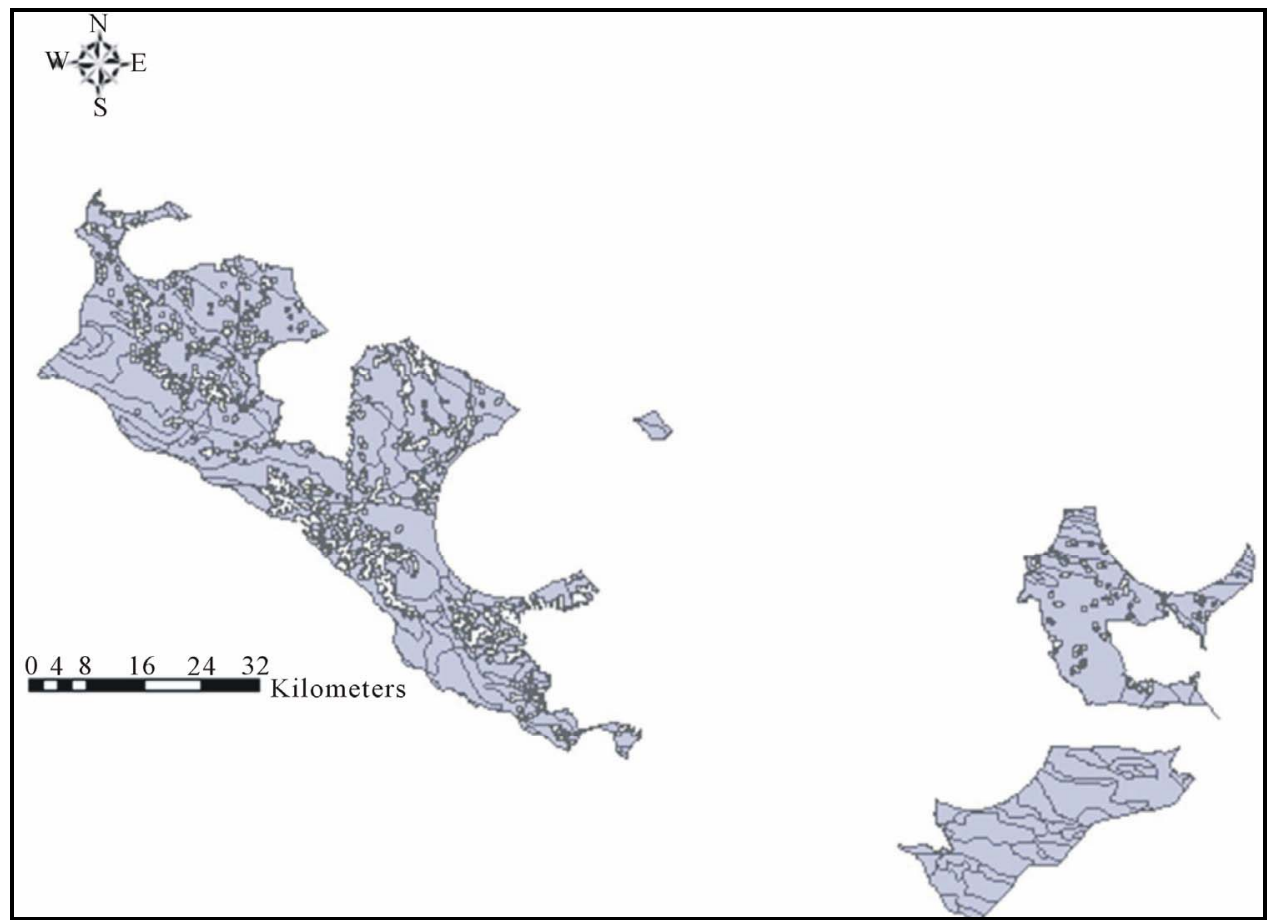

Figure 4. the suitable region of study area with DOE criteria.

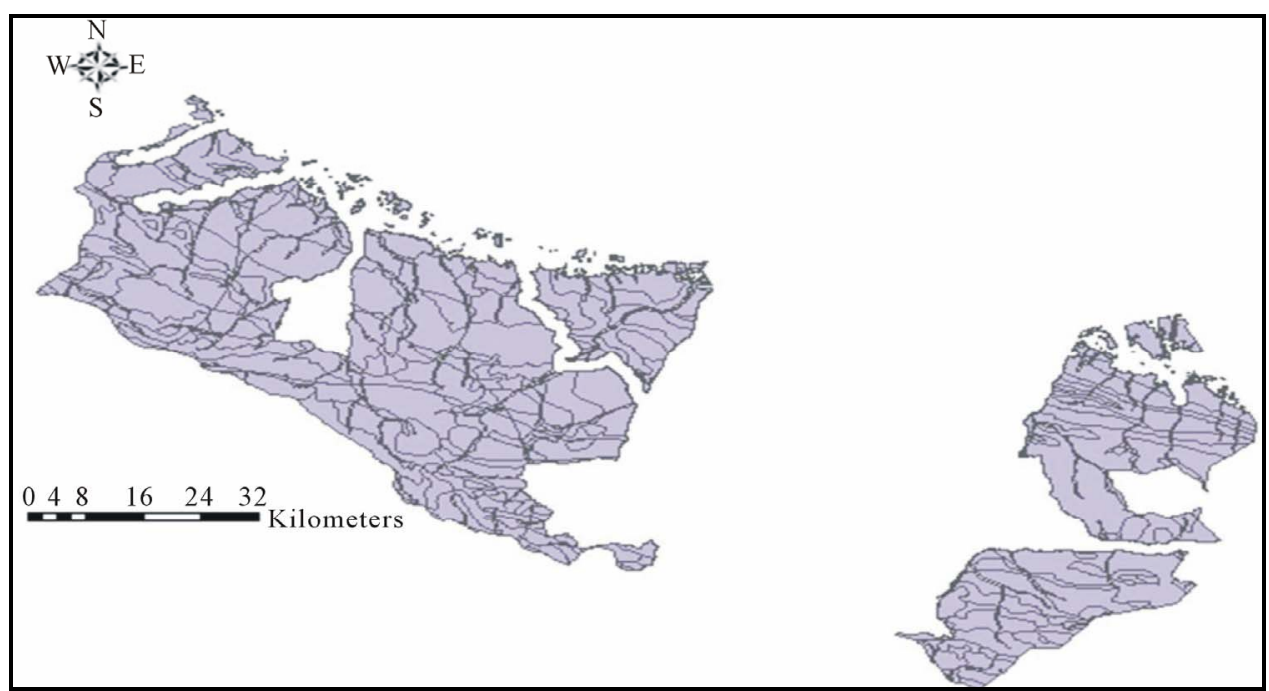

Figure 5. the suitable region of study area with Management and planning organization criteria.

Table 2. The proportion of the study area with the standard.

\begin{tabular}{ccccc}
\hline \multicolumn{2}{c}{ Hectare } & \multicolumn{2}{c}{ Percent } & \multirow{2}{*}{ Methods } \\
\cline { 1 - 4 } Unsuitable & Suitable & Unsuitable & Suitable & \\
\hline 326298.7658 & 541252.8 & 37.62 & 62.38 & BC \\
445963.7558 & 421587.81 & 51.5 & 48.5 & $\begin{array}{c}\text { Management and } \\
\text { planning } \\
\text { organization of Iran } \\
\text { Iran Department of } \\
\text { Environment }\end{array}$ \\
\hline
\end{tabular}

The entire area of study area on GIS map is around 867551.5658 hectare.

\section{REFERENCES}

[1] M. Z. Siddiqui, "Landfill Siting Using Geographic Information Systmes: A Demonstration," Journal of Environmental Engineering, Vol. 122, No. 6, 1996, pp. 515523. doi:10.1061/(ASCE)0733-9372(1996)122:6(515)

[2] T. D. Kontos, D. P. Komilis and C. P. Halvadakis, "Siting MSW landfills in Lesvos Island with a GIS-Based Methodology," Waste Management and Research, Vol. 21, No. 3, 2003, pp. 262-327. doi:10.1177/0734242X0302100310

[3] O. B. Delgado, M. Mendoza, E. L. Granados and D. Geneletti, "Analysis of Land Suitability for the Siting of Inter-Municipal Landfills in the Cuitzeo Lake Basin," 
Mexico Waste Management, Vol. 28, No. 7, 2008, pp. 11371146. doi:10.1016/j.wasman.2007.07.002

[4] S. Dipanjan, T. Vinod and D. Onkar, "Ranking Potential Solid Wastes Disposal Sites Using Geographic Information System Techniques and AHP," National Seminar on Applications of GIS for Solving Environmental Problems, Chennai, 6-8 August 1997, pp. 98-106.

[5] V. R. Sumathi, U. Natesan and C. Sarkar, "GIS-Based Approach for Optimized Siting of Municipal Solid Waste Landfill," Waste Management, Vol. 28, No. 11, 2008, pp. 2146-2160.

[6] M. Moeinaddini, N. Khorasani, A. Danehkar, A. A. Darvishsefat and M. Zienalyan "Siting MSW Landfill Using Weighted Linear Combination and Analytical Hierarchy Process (AHP) Methodology in GIS Environment (Case Study: Karaj)," Waste Management, Vol. 30, No. 5, 2010, pp. 912-920.

[7] M. A. Abdoli, "Recycling of Municipal Solid Wastes," Tehran University, Iran, 2005.

[8] E. Q. Panahandeh, "Recycling of Municipal Organic Matter of Solid Waste (Compost)," Recycling Organization, Isfahan Municipality, 2006.

[9] A. Rahim and M. M. Fazel, "Pathological Approach to Achieve the Desired Eye View of the Environment in 20 Years," 3rd National Conference on Waste Management and Its Role in Urban Planning, 21-22 April 2007.
[10] F. Calvo, B. Moreno, A. Ramos and M. Zamorano, "Implementation of a New Environmental Impact Assessment for Municipal Waste Landfill as Tool for Planning and Decision-Making Process," Renewable and Sustainable Energy Reviews, Vol. 11, No. 1, 2007, pp. 98-115. doi:10.1016/j.rser.2004.12.003

[11] L. F. Diaz, G. M. Savage and L. L. Egerth, "Alternatives for the Treatment and Disposal of Healthcare Waste in Developing Countries," Waste Management, Vol. 25, No. 6, 2005, pp. 626-637.

[12] F. Calvo, B. Moreno, M. Zamorano and M. Szanto, "Environmental Diagnosis Methodology for Municipal Waste Landfills," Waste Management, Vol. 25, No. 8, 2005, pp. 768-779.

[13] Iranian Statistics Center, "General Census of Population and Housing of Mazandaran Province," Iran, 2010.

[14] "Mazandaran Landuse Planning Book," Department of Planning Office, Mazandaran Governor, Iran, 2009.

[15] M. Zamoranoa, E. Molerob, A. Hurtadoa, A. Grindlay and A. Ramos, "Evaluation of a Municipal Landfill Site in Southern Spain with GIS-Aided Methodology," Journal of Hazardous Materials, Vol. 160, No. 2-3, 2008, pp. 473-481. doi:10.1016/j.jhazmat.2008.03.023

[16] J. Malczewski, "GIS-Based Land-Use Suitability Analysis: A Critical Overview," Progress in Planning, Vol. 62, No. 1, 2004, pp. 3-65. doi:10.1016/j.progress.2003.09.002 